\title{
REVIEW
}

\section{SALIVARY $\alpha$-AMYLASE AND CHROMOGRANIN A IN ANXIETY-RELATED RESEARCH}

Valeria T. Tananska

Department of Anatomy, Histology and Embryology, Medical Faculty, Medical University, Plovdiv, Bulgaria

\section{СЛЮННЫЕ $\alpha$-АМИЛАЗА И ХРОМОГРАНИН А В ИССЛЕДОВАНИЯХ ТРЕВОЖНОСТИ}

Валерия Т. Тананска

Кафедра анатомии, гистологии и эмбриологии, Медицинский факультет,Медицинский университет, Пловдив, Болгария

\begin{abstract}
Salivary $\alpha$-amylase (sAA) and chromogranin $\mathrm{A}(\mathrm{sCgA})$ are at the forefront of current biochemical research on anxiety. Their use is being driven by the sudden surge of interest in "salivaomics," a new field in medicine studying saliva's genetic code, proteome and methabolom. Interestingly, it is not the primary functions of the enzyme and the protein, but the ingenious capture of their secondary ones (maintenance of the acid-alkaline balance and bactericidal / antifungal action) that allows for a swift, precise and pain-free measurement under physical and mental duress. Upon stimulation, sAA and sCgA are almost simultaneously released. Studying them allows a closer look at the autonomic nervous system (ANS) as opposed to the hypothalamic-pituitary-adrenal axis (HPA), which involves a long cascade of complex, hard to measure and interpret bio-chemical reactions.
\end{abstract}

Keywords: anxiety, salivary bio-markers, $\alpha$-amylase, chromogranin A

Folia Medica 2014; 56(4): 233-236

Copyright (C) 2014 Medical University, Plovdiv

\section{РЕЗЮМЕ}

Слюнные альфа-амилаза и хромогранин А являются основными биохимическими компонентами современных научных исследований в области тревожности. Их широкое применение обусловлено нарастающим в последнее время интересом к "salivaomics“, новому направлению медицины, предметом исследований которого являются генетический код, протеом и метаболом слюны. Объектом интереса являются не основные функции энзима и протеина в человеческом теле, а вторичные. Они проявляются в поддерживании кислотно-щёлочного равновесия и оказывают бактерицидно/ антифугальное действие. Данные функции, активированные во время умственной и физической тревожности, обеспечивают быстрый, точный и безболезненный учёт изменений в обоих биомаркерах. Преимуществом слюнных альфа-амилазы и хромогранина А является тот факт, что во время стимуляции они выделяются почти одновременно. Их замер делает возможным изучение функциональных механизмов автономной нервной системы (ANS), а не гипоталамо-гипофизно-адренальной системы (НРА). Данная система характеризуется длинной цепью сложных биохимических реакций, которые затрудняют измерение и интерпретирование.

Ключевые слова: тревожность, слюнные биомаркеры, $\alpha$-амилаза, хромогранин $A$

Folia Medica 2014; 56(4): 233-236

(C) 2014 Все права защищены. Медицинский университет, Пловдив

\section{INTRODUCTION}

Biochemical testing for anxiety is concerned with two key neuro-endocrine systems. The first one is the hypothalamic-pituitary-adrenal axis (HPA) which regulates the release of the glucocorticosteroid cortisol. The second one is the sympathetic-adrenalmedullary system (SAM) controlling the secretion of catecholamines.

Within the HPA axis, the level of cortisol is measured in plasma, urine and saliva. The quanti- fication of its fluctuations however is problematic due to slow release, sex-expressed differences and diurnal/ seasonal cyclicity. ${ }^{1}$

A follow up on the SAM system has its own shortcomings. Catecholamines may metabolize fast (within $1-3$ minutes), but their half-life is equally short and their diurnal oscillation - unstable. ${ }^{2}$ Besides, blood collection is traumatic and can be, in itself, the cause for rising anxiety.

In a search for alternative bio-markers, charac- 
terized by non-invasive biological collection and precise measurement, scientists have turned their attention towards $\alpha$-amylase and chromogranin $\mathrm{A}$. The test medium is saliva.

\section{SALIVA}

Saliva is a watery liquid devoid of color, taste and odor. Its main role in the body is to moisturize and chemically process food that has been mechanically broken by the teeth.

A healthy human produces between $700 \mathrm{ml}$ and 11 of saliva every 24 hours. Although the precise composition varies from person to person, the following elements are generally observed:

- water $(99 \%)$

- enzymes (acidic phosphatases, lactoperoxidase)

- salivary mucins

- electrolytes (sodium, potassium, calcium, magnesium, chlorides, bicarbonates, phosphates)

- mucus (glycosaminoglycans and glycoproteins)

- over 700 "good" bacteria (assisting food digestion, fighting against "bad" bacteria)

- anti-bacterial agents (thiocyanate, hydrogen peroxide, secretionary immunoglobulin-A, lactoperoxidase).

Saliva is released in the buccal cavity via the three main pairs of exocrine glands (the parotid, the submandibular and the sublingual), 600 secondary glands and Von Ebner's auxiliary glands.

The secreting activity and the vascularization of these glands are controlled by the autonomic nervous system (ANS). The parasympathetic innervation is executed by branches of the facial (VII cranial nerve) and glossopharyngeal (IX cranial nerve) nerves, while the sympathetic innervation - by the superior cervical ganglion (SCG).

In the absence of a particular stimulus (e.g. food, anxiety), $66 \%$ of saliva's volume is provided by the submandibular glands, $23 \%$ - by the parotid, around $3 \%$ by the sublingual and the remaining $7-8 \%$ - by smaller glands.

Stimulation alters these figures. The first two in the list switch places, and the parotid glands take over two thirds of saliva's provision. ${ }^{3}$

The changes in volume are matched also by changes in relative composition. The usual $99 \%$ of water decrease in favor of larger amounts of mucus and organic and non-organic matter.

It is precisely this dynamic nature that has elevated saliva in the eyes of biochemists. As a consequence, the past ten years have witnessed a veritable boom in salivary research. 2004 saw the uncovering of saliva's genetic code, 2007 - of its proteome, and 2009 - of its methabolom. ${ }^{4}$ A new term "salivaomics" now reflects the branch in medicine studying saliva's bio-chemical composition. ${ }^{5}$ It informs the scientific interest in the changing levels of salivary $\alpha$-amylase and chromogranin A in anxiety research.

\section{a-AMYLASE (AA)}

$\alpha$-amylase or ptyalin is a key digestive enzyme that is released in saliva by the acinae of the three main salivary gland pairs. It breaks down starches prior to bolus' passing in the esophagus and decomposes food residue between individual teeth, on the gums and the tongue. ${ }^{6}$

Despite its invaluable place in digestion, scientists now look more towards AA's secondary function - sustaining the acid-alkaline balance of the human body. It has long been established that anxiety triggers sympathetic response and the release of epinephrine (adrenalin). Epinephrine binds to the $\alpha$ and $\beta$ adrenergic receptors in body tissues.

Of special interest here are the $\beta 1$ и $\beta 2$ adrenergic receptors. $\beta 1$ adrenergic receptors are located mainly in the heart and kidneys, while $\beta 2$ - in the lungs, the gastrointestinal tract, the liver, vascular smooth muscle, the uterus and skeletal muscles. When binding with epinephrine, they:

- quicken heart's pumping traction

- stimulate kidney function and the release of renin

- cause bronchodilation

- suppress digestion and intestinal motility

- increase blood flow to skeletal muscles

- ensure the glycogenolysis process in the liver?

By doing so, $\beta$ adrenergic receptors put tissues in excitory mode. This emergency regime allows the body to deal successfully with the stressor.

Research has found this type of receptors also in the basolateral membrane of salivary glands' acinae. This discovery signifies that the secretion of epinephrine raises the level of $\alpha$-amylase in saliva. ${ }^{8}$

It is important to note that the digestive enzyme functions best at a slightly alkaline $\mathrm{pH}$ level of 7.4 - 7.6. When he body is stressed, the normal $\mathrm{pH}$ level of tissues (7.0) drops precipitously into the acidic band. ${ }^{9}$

Placed in a hostile, acidic environment, human proteins start disintegrating, enzymes lose their effective power. With sustained anxiety, the metabolic system suffers chronically. Disease develops in vulnerable tissues. The immune system gets taxed.

The human body has some compensatory mecha- 
nisms to counteract such detrimental effects. One of them is the increased release of substances with alkaline $\mathrm{pH}$, the $\alpha$-amylase inclusive. As a result, the acid-alkaline homeostasis in the oral cavity is redressed either to its previous levels, or according to the 'equilibrium law' of Chatelier, to new, adapted levels. ${ }^{10}$

\section{CHROMOGRANIN A (CgA)}

Chromogranin $\mathrm{A}$ is an acidic protein, a member of the chromogranin-secretogranin family.

It is also a pro-hormone. Its composition of 439 base amino-acids acts as the building blocks for more complex amino-acids. Peptides built from $\mathrm{CgA}$ fragments (e.g. pancreastatin, vasostatin I and II, catestatin) have autocrine, paracrine and endocrine function. Therefore, the back-to-back measure of high levels of $\mathrm{CgA}$ in plasma is considered a reliable indication for the presence of carcinogenic tumors (in $80 \%$ of cases), pheochromocytoma $(89 \%)$, gastrinoma $(100 \%)$ and other endocrinerelated illnesses. ${ }^{11}$

Post chemical synthesis, chromogranin A is stored in the secretory vesicles of adrenergic neurons and paraneurons in the:

- cerebellum, cerebral cortex, septum, the amygdaloid nucleus, the astroglial cells and the cerebral fluid

- neuro-endocrine cells of the small and large intestines, as well as in the pancreatic islets

- the submandibular glands ${ }^{12}$.

The normally sustained concentration of the protein in plasma and saliva is low. When a stimulus is applied, chromogranin A is released in:

- the blood - from the secretory vesicles of the adrenal medulla and the frontal portion of the pituitary gland, along the sympathetic branch of the autonomic nervous system (ANS)

- saliva - from the secretory vesicles of the submandibular glands, again along the ANS pathway.

Its activation is matched by that of epinephrine and norepinephrine, and is therefore reflective of changes in blood pressure and pulse. ${ }^{13}$

Why does anxiety trigger its release? Apart from being a protein, CgA's constituent fragments - prochromacin, chromacin I and chromacin II possess strong bactericidal and antifungal properties. They are activated to protect the human body from infection in times of a compromised immune system; in this case, when a strong stressor appears. ${ }^{14}$

\section{BENEFITS OF USING SALIVARY A-AMYLASE (sAA) AND CHROMOGRANIN A (sCgA) IN ANXI- ETY RESEARCH}

Pioneers and current leaders in anxiety research using salivary $\alpha$-amylase and chromogranin A are the Japanese scientists, famous with their precision and adherence to strict scientific protocol. They explore primarily stressors involved in mental tasks ${ }^{15}$, noise $^{16}$ or repetitive and monotonous activities ${ }^{17}$. These targets are encountered in many technicallyoriented jobs in Japan requiring endurance (e.g. accounting, office work, long-haul driving, defense provision, etc.).

In the medical field, Japanese scientists look at how both bio-markers fare in stressful medical treatment, for example, with tumor resection, radiation therapy or dental work. ${ }^{18-20}$

All Japanese research confirms the usefulness of $\alpha$-amylase and chromogranin A in anxiety studies, especially when verified with other measures such as self-assessment questionnaires, blood pressure and pulse measurements.

Such efforts have also been validated by other scientists around the world ${ }^{21,22}$, thus establishing a wealth of literature dealing with different anxietyrelated situations.

Amongst the discovered benefits of sAA and sCgA's use are:

- the non-invasive method for material collection - through passive drooling or the active chewing of a cotton swab. Studied subjects do not experience pain or anxiety due to painful testing protocols (e.g. needle penetration).

- an almost immediate release (10 - 15 minutes) upon stimulation, compared to a catabolic steroid hormone such as cortisol (25 - 30 minutes or longer after initial stimulus provision)

- the changes in both bio-markers match changes in blood pressure, breathing velocity and heart rhythm, thus solidifying the validity of one's research. ${ }^{23}$

- there is no significant difference across gender - both men and women show comparable anxiety levels, which implies that sex hormones do not influence $\alpha$-amylase and chromogranin A significantly. ${ }^{24}$

- the stable, aseasonal cyclicity - the circadian rhythm of $\mathrm{CgA}$ in healthy individuals shows a peak at 11.00 p.m. with $65.4(9.0) \mathrm{mg} / \mathrm{l}$ and a nadir in the morning at 8 a.m. with $43.1(6.6) \mathrm{mg} / \mathrm{l}$. Salivary $\alpha$-amylase levels increase normally in the morning until midday and decrease at night. ${ }^{25}$ A quick analysis of these timelines shows that the perfect time for simultaneous testing of both bio-markers 
is between 12.30 and 14.00 (on an empty stomach).

- the opportunity to study the ANS system as opposed to the HPA system, which involves a long cascade of complex, hard to measure and interpret bio-chemical reactions. Researchers can track acute as opposed to chronically expressed anxiety.

\section{CONCLUSION}

Research in salivary $\alpha$-amylase and chromogranin $\mathrm{A}$ is yet to make a deeper impact on medical and dental care. On one hand, it is itself the vehicle of precise and anxiety-free individual testing, while on the other, a window into the not so well understood workings of the autonomic nervous system.

\section{REFERENCES}

1. Hellhammer DH, Wust S, Kudielka BM. Salivary cortisol as a biomarker in stress research. Psychoneuroendocrinology 2009;34(2):163-71.

2. Dodt C, Breckling U, Derad I, et al. Plasma epinephrine and norepinephrine concentration of healthy humans associated with nighttime sleep and morning arousal. Hypertension 1997;30:71-6.

3. Holsinger FC, Bui DT. Anatomy, function and evaluation of the salivary glands. In Myers EN, Ferris ML, eds. Salivary Gland Disorders. NY: Springer; 2007:1-16.

4. Sugimoto M, Wong DT, Hirayama A, et al. Capillary electrophoresis mass spectrometry-based saliva metabolomics identified oral, breast and pancreatic cancer-specific profiles. Metabolomics 2010;6(1):78-95.

5. Yan W, Yu W, Than S, et al. Salivaomics knowledge base, Abstract 1179. Presentation at the 37th Annual meeting and exhibition of the American Association for Dental Research. Dallas (TX); 5 April 2008.

6. Turner RJ, Sugiya H. Salivary glands and saliva. Understanding salivary fluid and protein secretion. Oral Diseases 2002;8:3-11.

7. Perez DM. The adrenergic receptors in the $21 \mathrm{st}$ century. Totowa (NJ): Humana Press; 2005.

8. Castle D, Castle A. Intracellular transport and secretion of salivary proteins. Crit Rev Oral Biol Med 1998;9:4-22.

9. Ziemann AE, Allen JE, Dahdaleh NS, et al. The amygdala is a chemosensor that detects carbon dioxide and acidosis to elicit fear behaviour. Cell 2009;139(5):1012-21.

10. Bellingrath S, Kudielka BM. Effort-reward-imbalance and overcommitment are associated with hypothalamus-pituitary-adrenal (HPA) axis responses to acute psychosocial stress in healthy working school teachers. Psychoneuroendocrinology 2008;33: 1335-43.

11. Nobels FRE, Kwekkeboom D, Coopmans W, et al. Chromogranin A as serum marker for neuroendo- crine neoplasia: comparison with neuron-specific enolase and the alpha sub-unit of glycoprotein hormones. J Clin Endocrinol Metab 1997;82(8):2622-8.

12. Contrada RJ, Baum A, editors. The handbook of stress science: biology, psychology and health, New York, NY: Springer.

13. Takiyyuddin MA, Cervenka JH, Sullivan PA, et al. Is physiologic sympathoadrenal catecholamine release exocytotic in humans? Circulation 1990;81(1): 185-95.

14. Lugardon K, Raffner R, Goumon Y, et al. Antibacterial and antifungal activities of vasostatin-1, the n-terminal fragment of chromogranin A. J Biol Chem 2000;275:10745-53.

15. Nakane H, Asami O, Yamada Y, Harada T, Matsui $\mathrm{N}$, Kanno T, et al. Salivary chromogranin A as an index of psychosomatic stress response. Biomed Res 1998;19:401-6.

16. Miyakawa M, Matsui T, Kishikawa H, et al. Salivary chromogranin $\mathrm{A}$ as a measure of stress response to noise. Noise and Health 2006;8(32):108-13.

17. Yamakoshi T, Park SB, Jang WC, et al. Relationship between salivary chromogranin-A and stress induced by simulated monotonous driving. Med Biol Eng Comput 2009;47(4):449-56.

18. Masaya U, Nabeya Y, Takashi A, et al. Salivary amylase activity is useful for assessing perioperative stress in response to pain in patients undergoing endoscopic submucosal dissection of gastric tumor under deep sedation. Gastric Cancer 2010;13(2):84-9.

19. Seki-Nakamura K, Maebayashi K, Nasu-Izumi, S, et al. Evaluation of anxiety and salivary chromogranin A secretion in women receiving breast conserving surgery followed by radiation therapy. J Radiat Res 2011;52(3):351-9.

20. Mitsuhata C, Ohara Y, Tachikake M, et al. Effectiveness of salivary chromogranin A as a stress index in young children during dental treatment. Pediatric Dental Journal 2012;22(2):163-9.

21. Haririan H, Bertl K, Laky M, et al. Salivary and serum chromogranin A and alpha-amylase in periodontal health and disease. J Periodontol 2012;83(10):1314-21.

22. Granger DA, Kivlighan KT, el-Sheikh M, et al. Salivary alpha-amylase in biobehavioral research: recent developments and applications. Ann N Y Acad Sci 2007;1098:122-44.

23. Nozaki S, Tanaka M, Mizuno K, et al. Mental and physical fatigue-related biochemical alterations. Nutrition 2009;25(1):51-7.

24. Filaire E, Dreux B, Massart A, et al. Salivary alphaamylase, cortisol and chromogranin A responses to a lecture: impact of sex. Eur J Appl Physiol 2009;106(1):71-7.

25. Nater UM, Rohleder N, Scholtz W, et al. Determinants of the diurnal course of salivary alpha-amylase. Psychoneuroendocrinology 2007;32(4):392-401. 